\title{
MANAGEMENT PRACTICES AND COST SYSTEM DESIGN: EVIDENCE FROM JORDANIAN MANUFACTURING COMPANIES

\author{
Majdy I. Zuriekat
}

Graduate School of Business Administration, German Jordanian University, Jordan. Email: majdy.zuriekat@gju.edu.jo

\author{
Article History: Received on $16^{\text {th }}$ January 2020, Revised on $26^{\text {th }}$ February 2020, Published on $07^{\text {th }}$ March 2020
}

\begin{abstract}
Purpose: The purpose of this study is to reveal and examine the nature of costing systems design alongside the usage of new manufacturing practices in Jordanian Manufacturing Companies.

Design/Methodology/Approach: For carrying out the study, 86 managers from 43 manufacturing companies received the study questionnaire from which 56 were valid for data analysis. The study results are presented using multiple regression analysis.
\end{abstract}

Findings: The results using multiple regressions indicate that Just in Time (JIT), Total Quality Management (TQM) and Product Diversity (PD) has a significant influence on costing systems design.

Implications: This study provides evidence on the importance of using management practices as a driver for companies to use a broader perspective for designing costing systems. Responding managers have now empirical evidence regarding the manufacturing practices needed to design costing systems to their companies.

Originality/Value: This is the first attempt to examine the manufacturing practices as a driver for cost system design. The study also provides significant managerial implications on how to use manufacturing practices to ensure better cost system design.

Keywords: Cost System Design, Total Quality Management, Just in Time, Product Diversity.

\section{INTRODUCTION}

In recent years, great effort has been given to studying the level of complexity when designing costing systems in manufacturing companies. High competition in markets in terms of quality, price, and services has also increased the management need to rely on accurate cost information (Ammar, 2017). The Competitive environment has encouraged manufacturing companies to use new management practices that support managers to focus on having greater product diversity and services.

Management accounting scholars have expressed concerns related to using conventional bases such as machines and labor hours to allocate overhead costs (Boerema, Van Passel, \& Meire, 2018). Such conventional costing systems normally provide managers with specified and irrelevant cost information about products and services (Johnson \& Kaplan, 1987). Thus, understanding the design of costing systems through determining appropriate allocation basis for manufacturing overhead has become essential in the decision-making process (Gunasekaran, Marri, \& Yusuf, 1999; Shea, Waldrup, Xu, \& Williamson, 2018).

In the past century, the activity-based costing system (ABC) was introduced to companies as a new allocation system that overcomes the disadvantages of the conventional costing system (Drury, 2013). The ABC system provides companies with manufacturing overhead rates that are accurate for costing and pricing decisions. It also provides relevant cost information that helps managers in making profitable decisions to compete in highly competitive markets (Drury \& Tayles, 2005).

The adoption level of an activity-based costing system has been extensively studied in the literature (Bjørnenak, 1997; Brierley, 2008; Malmi, 1999; Uyar \& Kuzey, 2016). The idea behind the ABC system is that it logically accumulates first recourse costs to business activities, and then allocates these activity costs to companies' products or services. The $\mathrm{ABC}$ system is considered not only a costing system but also a managerial decision-making tool to enhance companies' performance (Kennedy \& Affleck-Graves, 2001; Schoute \& Budding, 2017; Wu, Boateng, \& Drury, 2007). According to Drury and Tayles (2005), the previous empirical research on costing systems has focused on studying activity-based costing systems. This stream of research falls into four categories. The first set of empirical research (Al-Omiri \& Drury, 2007; Innes \& Mitchell, 1995) has described the characteristics and applications of ABC systems. The second set of empirical research (Bjørnenak, 1997; Krumwiede, 1998) has followed the contingency theory, the framework to study the level of companies' usage of such costing systems. The third set of empirical research (Cagwin \& Bouwman, 2002; Kennedy \& Affleck-Graves, 2001) has shown the relationship between using ABC systems and improvements in companies' performance as an outcome construct. Finally, several researchers (Cagwin \& Bouwman, 2002; Shields, 1998) have focused on studying companies who succeed and/or failed in implementing the ABC system with great emphasis on the reasons for the identified outcome and experience.

Despite the great attention given to $\mathrm{ABC}$ research streams, there was an agreement among management accounting researchers that the technical conditions under the adoption of $\mathrm{ABC}$ and organizational effectiveness have been overstated. Furthermore, the inconsistency in research findings from previous empirical surveys worldwide was poorly introduced in the literature and in practice (Abernethy, Lillis, Brownell, \& Carter, 2001; Cinquini, Collini, Marelli, \& 
Tenucci, 2015). With respect to all ABC research, this paper supports the need for sophisticated costing systems design to cope with the new changes in all business environments. Manufacturing companies, in particular, are facing an increased level of competition, deregulation of domestic markets, and demands for greater product diversity to satisfy customers (Pavlatos \& Kostakis, 2015). Therefore, managers are now willing to take actions related to decreasing and controlling the cost of their manufacturing processes and products, and these actions need reliable cost information systems (Cinquini et al., 2015).

It should be recognized at the outset that research related to the complexity of costing system has assumed that all costing systems utilized in companies are either traditional (unsophisticated) or activity-based costing (sophisticated) (Brierley, 2008; Brown, Booth, \& Giacobbe, 2004). Other research studies related to the complexity of costing systems have focused on studying only the level of ABC usage (Wu et al., 2007). However, the inconsistency in the findings of previous research studies related to costing systems' applications has caused more research investigation related to cost system design. Empirical research has reported different levels of usage of $\mathrm{ABC}$ systems in manufacturing (Abdel-Kader \& Luther, 2006; Anderson \& Young, 1999; Moschidis, Chatzipetrou, \& Tsiotras, 2018). Previous literature has also asserted that manufacturing companies are designing costing systems according to several factors such as the level of products' diversity, level of competition and the degree of sophistication in the operations' systems (Al-Omiri \& Drury, 2007; Ammar, 2017).

Extensive attention has been given to studying cost system design in manufacturing companies worldwide. This concentration was identified as a response to the increase in the level of competition in local and global marketplaces, deregulation of domestic markets, and customers' demand for greater product diversity. However, little attention was given to studying cost system design and management practices in developed countries. Moreover, there is a great need to investigate how Jordanian manufacturing companies are designing their cost systems to meet managers' demand for reliable cost information to make profitable decisions. Thus, the explicit purpose of the current study is to investigate how Jordanian manufacturing companies are designing their cost systems in terms of the number of cost pools and cost drivers. It has also been argued that the use of management practices such as TQM and JIT influence companies' costing system design. Thus, it is anticipated that this study would support Jordanian manufacturing companies when designing their costing systems to remain sustainable.

\section{LITERATURE REVIEW}

As mentioned earlier, the literature on cost systems design had focused on the $\mathrm{ABC}$ system in terms of adoption rates, usage rates and issues related to the outcomes of using activity-based costing (Brown et al., 2004; Drury \& Tayles, 2006; Wu et al., 2007). While surveys on the conventional cost systems design have examined the basis of cost allocation and have consistently shown machine and labor hours to be the main bases (Armitage, Webb, \& Glynn, 2016; Pierce \& Brown, 2006). Studies on cost system design have been conducted under the contingency theory framework.

Earlier, Cooper and Zmud (1990) empirical study examined the effect of several contextual factors on the ABC system implementation stages. They found that product complexity and new technologies usage had a significant influence on ABC system implementation. Bjørnenak (1997) investigated the characteristics of the activity-based costing systems in the manufacturing companies in Norway. They found that approximately $40 \%$ of the responding companies are either using the $\mathrm{ABC}$ system or planning to use it in the near future. Moreover, their results showed that cost behavior is the only contextual factor that had a significant effect on the level of usage of the activity-based costing system. While product diversity and level of market competition factors had shown no effect on companies using ABC systems. Gosselin (1997) reported in his study reported that centralized and formalized companies are implementing activitybased costing systems.

Early $\mathrm{ABC}$ proponents asserted that companies who are using more activity allocation bases have more advantages over companies who are using conventional allocation bases (Ratnatunga, 1999). Empirical ABC research (Anderson, 1995; Boerema et al., 2018; Pierce \& Brown, 2006) had neglected to study the level and degree of ABC implementation stages. In this context, Krumwiede (1998) argued that the implementation levels of activity-based costing should be nine. He also found in his study on $\mathrm{ABC}$ level of implementation that companies' size, top management support and level of cost distortion are the significant contextual factors that influence companies with higher levels of implementation of activity-based costing systems. Recent researchers, however, have extended their arguments on the importance of cost system design and $\mathrm{ABC}$ systems not only as systems to provide cost information but also as an effective managerial tool to make decisions on both operational and strategic levels (Innes and Mitchell, 1995; Innes, Mitchell, and Sinclair, 2000; Drury, 2013; Uyar and Kuzey, 2016).

Following the contingency framework, McGowan and Klammer (1997) examined employees' level of satisfaction with their costing systems. They found that the level of employees' satisfaction was higher for companies that are using activity-based costing systems. In a similar vein, Kennedy and Affleck-Graves (2001) investigated firms' value as an outcome variable and the choice of activity-based costing systems. Their study reported responding companies who are using activity-based costing systems to have greater firms' value over consecutive years. Cagwin and Bouwman (2002) also found that responding companies who were using activity-based costing systems reported significant progress in the return on investment.

The costing system is considered a fundamental field of management accounting practices. Therefore, companies should design their costing systems accurately to provide managers with relevant information on their activities, products and 
customers' profitability to compete in today's competitive environment (Drury and Tayles, 2005). Moreover, classifying companies according to the level of sophistication of its costing systems is practically considered difficult due to the variation in the level of sophistication among different companies (Al-Omiri \& Drury, 2007; Brierley, 2008). Therefore, the chances are high that although companies may have implemented the same innovation in terminology, the actual management accounting systems and practices may be very different (Chenhall, 2003). Moreover, such sources of variation can have profound effects on the outcomes that are observed.

The above literature and arguments support the idea that classifying the characteristics of cost system design into traditional and ABC systems are difficult. Thus, this study adopts a model developed by Drury and Tayles (2005) to measure cost system design by identifying the number of activities and activity pools and drivers. This measurement model of the cost system design is considered relevant and valid by several management accounting researchers (Ratnatunga, 1999; Brierley, 2008; Schoute \& Budding, 2017; Ammar, 2017). Moreover, the previous literature review suggests that contextual factors may influence cost system design (Chenhall, 2003; Dent, 1990). Thus, this study investigates the relationship between three management practices and cost system design. The management practices included in the current study are total quality management, just-in-time manufacturing system, and product diversity.

\section{RESEARCH CONSTRUCTS \& HYPOTHESES}

The previous literature review on cost system design has identified the need for more research studies on how companies are designing their costing systems. Moreover, this study provides more insights into the anticipated relationship between three management practices and cost system design.

Recent development identified in the external environment has encouraged companies worldwide to invest in several management practices. These managerial practices, on the one hand, supported managers in their day-to-day operations. On the other hand, the increased level of competition related to pricing products accurately has resulted in a greater need for a more accurate costing system and the need for more detailed cost information (Chenhall, 2003). Therefore, companies should design their costing systems to provide the required cost information about activities, products, and customers (Baines and Langfield-Smith, 2003). Finally, managers should design their costing systems by following the management practices used by their companies to gain a competitive advantage.

\section{Total Quality Management}

In response to the increased level of competition, manufacturing companies have paid great attention to different quality initiatives in the manufacturing processes. These quality initiatives helped companies produce and deliver high-quality products to customers (Chenhall, 2003; Haroun, 2015). The importance of quality initiatives to companies has resulted in promoting and developing quality initiatives to become a managerial practice, which is called total quality management.

It has been argued in the management accounting literature that companies utilizing total quality management aspects have achieved higher levels of customer satisfaction and performance. Moreover, researchers (McAdam \& Bannister, 2001) provided evidence on the importance of using total quality management in operations to gain a competitive advantage over competitors. The association between total quality management and cost system design has been reported in several studies (Drury \& Tayles, 2006; Wu et al., 2007). Abdel-Kader and Luther (2008) found in their study that responding companies who reported using total quality management have sophisticated costing systems in terms of activity allocation bases. Recently, Ahmad (2015) recommended using a sophisticated cost allocation bases to assist manufacturing companies who are using total quality management in the production processes. This notion was also evidenced by several empirical studies (Shields, 1998; Innes et al., 2000; Pierce and Brown, 2006). Consequently, this study argues that manufacturing companies following quality initiatives are following a unique cost system design in terms of number activity allocation bases when designing their costing systems. Therefore, the current study hypothesizes that:

H1: Total quality management has a significant positive effect on the design of costing systems.

\section{Just in Time}

Controlling manufacturing costs is considered one of the managerial practices that are currently followed by managers in order to reduce operating costs without affecting the quality of products. One of these managerial practices used by companies is known as just in time practice. According to Dale, Cooper, and Wilkinson (1997), this practice focuses on continuous improvement of manufacturing activities and processes to reduce time, defects and waste in all production departments which yield to decrease costs and improve productivity (Fullerton \& McWatters, 2002).

Moreover, researchers recommending the use of sophisticated cost allocation bases to assist manufacturing companies in identifying the production processes that need improvements. This recommendation was also supported by several empirical studies (Young \& Selto, 1991). Furthermore, Upton (1998) indicated that the sophisticated costing systems in terms of activity allocation bases are a central key feature for companies utilizing continuous improvement initiatives such as just in time system. Al-Omiri and Drury (2007) reported in their study that the increased number of manufacturing overhead allocation bases was identified in manufacturing companies who reported using continuous improvement initiatives. This study, however, argues that manufacturing companies adopting continuous improvement initiatives are following a unique cost system design in terms of number activity allocation bases. Therefore, the current study hypothesizes that: 
H2: Just-in-time has a significant positive effect on the design of costing systems.

\section{Product Diversity}

In the past, most companies produced a limited variety of products. Thus, it was not cost-effective to utilize more sophisticated costing systems. Recently, conditions have changed; many companies now produce and sell a large variety of products that consume different types of indirect manufacturing costs (Cinquini et al., 2015). Therefore, traditional costing systems are no longer appropriate to assign indirect manufacturing costs. On the one hand, product diversity is concerned with different types of manufacturing activities, including operating and service activities that are aligned to achieve organizational production plans (Drury \& Tayles, 2005). While, product diversity, on the other hand, is concerned with the number of products manufactured by companies.

It can be argued that manufacturing companies are required to focus on diversified products to respond to customers' demands. However, more diversified products need extra efforts when controlling and allocating manufacturing overhead over the number of products. Moreover, managers need accurate manufacturing cost information related to all products in order to make decisions and to compete in markets. Thus, companies with more diversified products will need more activities and costs that yield to the need to have more activity allocation bases. Such bases should be designed accurately to include both common overhead costs and customized overhead costs for each product type (Cinquini et al., 2015; Pavlatos \& Kostakis, 2015). This study, however, argues that manufacturing companies with diversified products are using a unique cost system design in terms of number activity allocation bases related to each product and related activities. Therefore, the current study hypothesizes that:

H3: Product diversity has a significant positive effect on the design of costing systems.

\section{CONSTRUCTS MEASUREMENT}

As argued in the previous section, the adoption of management practices by companies is considered a priority to achieve the operational and strategic objectives of companies. This has also made managers and companies to pay more attention to the design of companies' costing systems as a relevant information system. Moreover, management practices related to the manufacturing sector such as TQM, JIT and product diversity are set to be drivers for designing costing systems. These practices were measured in the current study based on previous management accounting research.

TQM is a continuous improvement philosophy adopted by all companies' members, functions and departments. This construct was measured in the current study by the level of companies' involvement in quality enhancement initiatives related to processes and practices. JIT is also a continuous improvement system that focuses on manufacturing practices related to the production systems. This construct was measured by the level of accuracy of production schedules, level of skills of production department staff and the level of waste reduction. Product diversity was measured by the extent of variation in the companies' products in terms of processes and required resources.

This study has pointed out that measuring cost system design is controversial among researchers. For example, several researchers (Bjørnenak, 1997; Krumwiede, 1998) have determined cost system design by the level of implementation of an activity-based costing system. Others (Drury \& Tayles, 2005) have determined cost system design by identifying the number of activities and activity drivers used for all types of manufacturing overhead costs. Therefore, the following items measured the cost system design construct in this study: (1) the number of identified cost pools in companies' cost system design. (2) the number of activity drivers set by companies to allocate manufacturing overhead costs per pools. Then these two item questions were combined and aggregated to determine cost system design in terms of complexity and variation. To test the validity of the cost system design construct, the correlation coefficient between the answers of respondents to the questions related to cost system design showed a high level of significant association $(0.628, p<0.01$; 2-tailed) between the items (Oppenheim, 2000) indicating that the construct is valid for testing hypotheses. Furthermore, the single correlation coefficient for each question to the aggregate scale of cost system design-construct were also found significant $(0.584, p<0.01 ; 2$-tailed $)$ and $(0.706, p<0.01$; 2-tailed) respectively. This measure of validity was recommended by (Bryman \& Cramer, 2002; Field, 2000; Hair JR, Babin, Money, and Samouel, 2003). In addition, all study constructs reported acceptable values of both skewness and kurtosis, as shown in Table 4.

\section{RESEARCH METHODOLOGY}

The study population is 66 manufacturing companies representing all industrial public shareholding companies listed in the Amman Stock Exchange by the end of the fiscal year 2018. The researcher sent an invitation letter to all companies to participate in the current study, followed by telephone calls to encourage companies to participate. At that stage, only 43 manufacturing companies agreed to participate. A well-structured questionnaire was utilized to collect the data as per earlier management accounting studies (Uyar \& Kuzey, 2016). Two managers responsible for production and finance were selected from each company (Hair, Black, Babin, Anderson, \& Tatham, 1998). The respondents were chosen, as they are familiar with the cost system design and the management practices of the current study. Questionnaires were handed to responding companies to facilitate the distribution and collection without disturbing companies' operations. Each company has assigned a contact person to contact the researcher when the questionnaire is filled and ready to collect. The researcher has distributed 86 questionnaires to the targeted respondents. The researcher collected 63 questionnaires from the 43 companies who agreed to participate. It should be noted that after screening the collected questionnaire, 7 incomplete questionnaires were disregarded. The current study resulted in 56 questionnaires representing a 61.5 percent response rate. 


\section{RESEARCH ANALYSIS \& FINDINGS}

The first part of the analysis provides a descriptive outline of the responding companies and respondents' profiles. It also shows how responding companies perceive their costing systems in terms of activity-based costing system level of consideration or/and implementation within companies' cost systems. The second part shows the hypotheses testing results.

\section{Descriptive Analysis}

Table 1 shows the frequencies and relative percentages concerning the industry category. The highest percentages of responding companies were in the field of beverage and food, pharmaceutical, and chemical. It can also be noted from Table 1 that individual respondents who filled the study questionnaires are seniors in their companies who are well informed about all study constructs. In addition, their level of experience in the company is considered relevant for the purpose of the current study.

Table 1: Industrial Sector and Respondents' Job Titles and Experience

\begin{tabular}{|c|c|c|}
\hline Industrial Sector & Frequency & Percent \\
\hline Beverage and Food & 10 & $23 \%$ \\
\hline Chemical & 7 & $16 \%$ \\
\hline Electrical & 4 & $9 \%$ \\
\hline Pharmaceutical & 9 & $21 \%$ \\
\hline Ceramic and Glass & 2 & $5 \%$ \\
\hline Extraction and Mining & 5 & $12 \%$ \\
\hline Textile and Clothing & 3 & $7 \%$ \\
\hline Cartoon and Paper & 3 & $7 \%$ \\
\hline Total & 43 & 100 \\
\hline Job Title & Frequency & Percent \\
\hline Senior Financial Accountant & 9 & $16 \%$ \\
\hline Senior Cost Accountant & 12 & $21 \%$ \\
\hline Financial Controller & 15 & $27 \%$ \\
\hline Production Manager & 13 & $23 \%$ \\
\hline $\mathrm{CFO}$ & 7 & $13 \%$ \\
\hline Not responded & - & - \\
\hline Total & 56 & 100 \\
\hline Experience in the Company & Frequency & Percent \\
\hline Less than 5 years & 7 & $12.5 \%$ \\
\hline 5 - less than 10 years & 11 & $19.5 \%$ \\
\hline 10 - less than 15 years & 22 & $40 \%$ \\
\hline $15-20$ years & 13 & $23 \%$ \\
\hline More than 20 years & 3 & $5 \%$ \\
\hline Not responded & 0 & $0 \%$ \\
\hline Total & 56 & 100 \\
\hline
\end{tabular}

Table 2 shows that more than $50 \%$ of the sample, according to respondents, are not reflecting activity-based costing in its systems. Moreover, less than $15 \%$ of the samples are studying introducing activity-based costing in their systems. In addition, the table shows that $14 \%$ are analyzing the objectives and benefits of this system to be implemented. Finally, the activity-based costing systems' implementation rate is also $14 \%$, thus, indicating a low level of implementation compared with worldwide manufacturing companies' level of implementation. 
Table 2: Activity-based costing (ABC) Level of Consideration/implementation

\begin{tabular}{lll}
\hline ABC System & $\begin{array}{l}\text { Responding } \\
\text { companies }\end{array}$ & Percent \\
\hline ABC system is not considered & 29 & $52 \%$ \\
\hline The Company is Considering ABC & 8 & $14 \%$ \\
\hline ABC was Considered then abandoned & 3 & $6 \%$ \\
\hline ABC is Approved for Implementing & - & - \\
\hline ABC is under Analysis & 8 & $14 \%$ \\
\hline ABC is Used & 8 & $14 \%$ \\
\hline ABC is Extensively Used & - & $\mathbf{1 0 0}$ \\
\hline Total & $\mathbf{5 6}$ & . \\
\hline
\end{tabular}

In addition, Table 3 shows how responding companies are designing their costing systems in terms of the number of manufacturing overhead cost drivers/pools. The table shows that only 49 companies were included in this analysis as 7 questionnaires were discarded for not answering the related questions.

Table 3: Number of Cost Pools/Drivers

\begin{tabular}{lll}
\hline Number of Cost Pools & Frequency & Percent \\
\hline One cost driver/pool & 4 & $8 \%$ \\
\hline $2-3$ cost drivers/pools & 7 & $14 \%$ \\
\hline $4-5$ cost drivers/pools & 11 & $23 \%$ \\
\hline $6-10$ cost drivers/pools & 14 & $29 \%$ \\
\hline $11-20$ cost drivers/pools & 11 & $22 \%$ \\
\hline $21-35$ cost drivers/pools & 2 & $4 \%$ \\
\hline $36-50$ cost drivers/ pools & - & - \\
\hline More than 50 cost driver/pools & - & - \\
\hline Total & $\mathbf{4 9}$ & $\mathbf{1 0 0}$ \\
\hline Number of Cost Drivers & Frequency & $\mathbf{P e r c e n t}$ \\
\hline One cost driver & 5 & $10 \%$ \\
\hline Two cost drivers & 11 & $23 \%$ \\
\hline Three cost drivers & 13 & $27 \%$ \\
\hline Four cost drivers & 6 & $12 \%$ \\
\hline Five cost drivers & 8 & $16 \%$ \\
\hline Six cost drivers & 4 & $8 \%$ \\
\hline 7-10 cost drivers & 2 & $4 \%$ \\
\hline More than 10 cost drivers & $\mathbf{4 9}$ & - \\
\hline Total & & $\mathbf{1 0 0}$ \\
\hline
\end{tabular}

\section{Hypotheses Testing}

Table 4 reports the Cronbach alphas, means, standard deviations and measures of both skewness and kurtosis. It can be noted from the table that the study constructs were valid and then appropriate to conduct the multiple regression analysis and test the study hypotheses. 
Table 4: Descriptive Statistics ( $\mathrm{n}=49$ )

\begin{tabular}{cccccc}
\hline Construct & Cronbach alpha & Mean & $\begin{array}{c}\text { Standard } \\
\text { deviation }\end{array}$ & Skewness & Kurtosis \\
\hline Product Diversity & 0.74 & 2.942 & 0.864 & 0.822 & 0.347 \\
\hline $\begin{array}{c}\text { Total Quality } \\
\text { Management }\end{array}$ & 0.78 & 2.850 & 0.688 & -0.695 & -0.239 \\
\hline Just in Time & 0.76 & 3.344 & 0.946 & 0.219 & 0.408 \\
\hline
\end{tabular}

Table 5 reports the correlation matrix for all study constructs (cost system design, product diversity, total quality management, and just in time). The table reports that all independent constructs (product diversity, total quality management and just in time) are significantly correlated $(p<0.01)$ with the dependent construct (cost system design). Moreover, total quality management is significantly correlated $(p<0.01)$ with just in time. This correlation is justified in the literature as companies who adopt quality initiatives can improve production processes in terms of saving time and reduce waste (Young \& Selto, 1991). Finally, both total quality management and just in time are not correlated with product diversity. This finding indicates that increasing product diversity is a response to the increasing level of competition in marketplaces, not an outcome of adopting management practices (Drury, 2013).

Table 5: Correlation Coefficients for Study Constructs

\begin{tabular}{lllll}
\hline & (1) & (2) & (3) & (4) \\
\hline (1) Cost System Design & 1 & & & \\
\hline (2) Product Diversity & $0.421^{* *}$ & 1 & & \\
\hline (3) Total Quality Management & $0.326^{* *}$ & 0.019 & $0.290^{*}$ & 1 \\
\hline (4) Just in Time & $0.350^{* *}$ & 0.140 & 0.060 & 0.120 \\
\hline
\end{tabular}

** Correlation significant at $\mathbf{p}<0.01$ (2-tailed)

* Correlation significant at $\mathrm{p}<0.05$ (2-tailed)

Table 6 presents the findings of the hypotheses testing based on multiple regression analysis. The $f$-value statistic shown in the table $(f=5.168)$ is significant $(p<0.01)$. The reported $\mathrm{R}^{2}=0.426$, which asserts that the independent constructs clarify $42.6 \%$ of the dependent construct. Finally, the results presented in Tables 5 and 6 show no support for the existence of multicollinearity.

Table 6: Multiple Regression Analysis

\begin{tabular}{llllll}
\hline Independent variables & Beta coefficients & t-value & p-value & Tolerance & VIF \\
\hline Constant & - & 4.723 & 0.001 & - & - \\
\hline Product diversity & 0.375 & 3.148 & 0.002 & 0.801 & 1.079 \\
\hline Total quality management & 0.346 & 2.405 & 0.004 & 0.694 & 1.470 \\
\hline Just in time & 0.321 & 2.283 & 0.035 & 0.763 & 1.852 \\
\hline $\mathbf{R}^{\mathbf{2}}$ & $\mathbf{0 . 4 2 6}$ & $\boldsymbol{f}$-value & $\mathbf{5 . 1 6 8}$ & Significance & $\mathbf{. 0 0 1}$
\end{tabular}

Based on the regression analysis outcomes, it can be concluded that hypotheses 1,2, and 3 are supported. This indicates that the sample manufacturing companies support the positive effect of product diversity, total quality management and just in time on cost system design. Beta values are $0.375,0.346$ and 0.321 respectively and the $t$-values are $3.148,2.405$ and 2.283 respectively.

\section{CONCLUSION \& DISCUSSION}

The current study utilized and redefined the cost system design presented and tested by Drury and Tayles (2005) study in the United Kingdom. This study also reviewed the relevant literature on cost accounting and activity-based costing. A major conclusion of the current study was related to the level of usage of activity-based costing systems. Despite the international recognition of activity-based costing systems (Cinquini et al., 2015; Krumwiede, 1998; Shea et al., 2018; Wu et al., 2007), the current study reported a low level of usage (14\%) of activity-based costing systems in the sample of manufacturing companies. This result might be justified, as management accounting techniques are still not yet well known for managers and decision-makers, especially in the manufacturing companies in Jordan. Furthermore, companies usually use some aspects of activity costing. Therefore, the respondents might not be aware of those aspects in their costing systems (Moschidis et al., 2018; Wu et al., 2007). Finally, arguments were raised by international management 
accounting researchers on how to measure the level of implementation of all management accounting techniques. Therefore, more investigation is needed to analyze and unify definitions of management accounting practices, then the level of implementation of an activity-based costing system would be clear to all researchers and companies (Chenhall, 2003). In terms of using cost pools by the responding companies, the results indicate that several types and numbers of cost pools have been widely used in the overall costing systems. However, 4-5, 6-10 and 11-20 cost pools are widely used in the costing systems by the responding companies. In terms of using cost drivers, the results indicate that several types and numbers of cost drivers have been widely used. However, 2 and 3 cost drivers were reported to be utilized in the design of costing systems. Further, the responding companies moderately rate the use of $1,4,5$, and 6 cost drivers in their costing systems.

The findings of the current study imply that product diversity is an important factor for managers to use more cost pools and cost drivers. This finding can be justified as companies who have a mix of production lines would have different cost structures, operations, and prices, thus, it is recommended to have more wide range of cost drivers and rates to allocated manufacturing overhead costs accurately (Schoute \& Budding, 2017). Therefore, it can be concluded that assigning overheads to activities is related to the level of diversity of products manufactured by the responding companies. Finally, the findings of the current study confirmed the positive relationship between management practices and cost system design (Bjørnenak, 1997; Malmi, 1999; Drury and Tayles, 2005; Boerema et al., 2018).

The current study has added managerial knowledge to users of management accounting practices as recommended by management accounting researchers (Al-Omiri \& Drury, 2007; Cinquini et al., 2015; Drury \& Tayles, 2005; Malmi, 1999). Managers in the Jordanian manufacturing sector can use the outcomes of the current study when designing their costing systems. This might also benefit them in determining and controlling products' costs for pricing decisions and setting strategies to compete in today's competitive environment.

\section{REFERENCES}

1. Abdel-Kader, M., \& Luther, R. (2006). Management accounting practices in the British food and drinks industry. British Food Journal, 108(5), 336-357. https://doi.org/10.1108/00070700610661321

2. Abdel-Kader, M., \& Luther, R. (2008). The impact of firm characteristics on management accounting practices: A UK-based empirical analysis. The British Accounting Review, 40(1), 2-27. https://doi.org/10.1016/j.bar.2007.11.003

3. Abernethy, M. A., Lillis, A. M., Brownell, P., \& Carter, P. (2001). Product diversity and costing system design choice: field study evidence. Management accounting research, 12(3), 261-279. https://doi.org/10.1006/mare.2001.0168

4. Ahmad, M. A. (2015). An Exploratory Study of Management Accounting Practices in Industrial Companies in Jordan (Case Study-Industrial Companies-ASE). Journal ofEconornic Theory, 9(1), 1-7.

5. Al-Omiri, M., \& Drury, C. M. (2007). A survey of factors influencing the choice of product costing systems in UK organizations. Management accounting research, 18(4), 399-424. https://doi.org/10.1016/j.mar.2007.02.002

6. Ammar, S. (2017). Enterprise systems, business process management and UK-management accounting practices: Cross-sectional case studies. Qualitative Research in Accounting \& Management, 14(3), 230-281. https://doi.org/10.1108/QRAM-05-2016-0044

7. Anderson, S. W. (1995). A framework for assessing cost management system changes: the case of activitybased costing implementation at General Motors, 1986-1993. Journal of Management Accounting Research, 7 , $1-51$.

8. Anderson, S. W., \& Young, S. M. (1999). The impact of contextual and process factors on the evaluation of activity-based costing systems. Accounting, Organizations and Society, 24(7), 525-559. https://doi.org/10.1016/S0361-3682(99)00018-5

9. Armitage, H. M., Webb, A., \& Glynn, J. (2016). The use of management accounting techniques by small and medium-sized enterprises: a field study of Canadian and Australian practice. Accounting Perspectives, 15(1), 31-69. https://doi.org/10.1111/1911-3838.12089

10. Baines, A., \& Langfield-Smith, K. (2003). Antecedents to management accounting change: a structural equation approach. Accounting, Organizations and Society, 28(7-8), 675-698. https://doi.org/10.1016/S03613682(02)00102-2

11. Bjørnenak, T. (1997). Diffusion and accounting: the case of ABC in Norway. Management accounting research, 8(1), 3-17. https://doi.org/10.1006/mare.1996.0031

12. Boerema, A., Van Passel, S., \& Meire, P. (2018). Cost-Effectiveness Analysis of Ecosystem Management With Ecosystem Services: From Theory to Practice. Ecological Economics, 15(2), 207-218. https://doi.org/10.1016/j.ecolecon.2018.06.005

13. Brierley, J. A. (2008). Toward an understanding of the sophistication of product costing systems. Journal of Management Accounting Research, 20(s1), 61-78. https://doi.org/10.2308/jmar.2008.20.s-1.61

14. Brown, D. A., Booth, P., \& Giacobbe, F. (2004). Technological and organizational influences on the adoption of activity-based costing in Australia. Accounting \& Finance, 44(3), 329-356. https://doi.org/10.1111/j.1467629x.2004.00118.x

15. Bryman, A., \& Cramer, D. (2002). Quantitative data analysis with SPSS Release 10 for Windows: A guide for social scientists: Routledge. https://doi.org/10.4324/9780203471548 
16. Cagwin, D., \& Bouwman, M. J. (2002). The association between activity-based costing and improvement in financial performance. Management accounting research, 13(1), 1-39. https://doi.org/10.1006/mare.2001.0175

17. Chenhall, R. H. (2003). Management control systems design within its organizational context: findings from contingency-based research and directions for the future. Accounting, Organizations and Society, 28(2-3), 127168. https://doi.org/10.1016/S0361-3682(01)00027-7

18. Cinquini, L., Collini, P., Marelli, A., \& Tenucci, A. (2015). Change in the relevance of cost information and costing systems: evidence from two Italian surveys. Journal of Management \& Governance, 19(3), 557-587. https://doi.org/10.1007/s10997-013-9275-4

19. Cooper, R. B., \& Zmud, R. W. (1990). Information technology implementation research: a technological diffusion approach. Management Science, 36(2), 123-139. https://doi.org/10.1287/mnsc.36.2.123

20. Dale, B. G., Cooper, C. L., \& Wilkinson, A. (1997). Managing quality and human resources: A guide to continuous improvement: Blackwell.

21. Dent, J. F. (1990). Strategy, organization and control: some possibilities for accounting research. Accounting, Organizations and Society, 15(1-2), 3-25. https://doi.org/10.1016/0361-3682(90)90010-R

22. Drury, C. (2013). Management and cost accounting: Springer.

23. Drury, C., \& Tayles, M. (2005). Explicating the design of overhead absorption procedures in UK organizations. The British Accounting Review, 37(1), 47-84. https://doi.org/10.1016/j.bar.2004.08.003

24. Drury, C., \& Tayles, M. (2006). Profitability analysis in UK organizations: an exploratory study. The British Accounting Review, 38(4), 405-425. https://doi.org/10.1016/j.bar.2006.05.003

25. Field, A. (2000). Discovering Statistics Using SPSS for Windows: Advanced Techniques for the Beginner. 2000: Sage Publication.

26. Fullerton, R. R., \& McWatters, C. S. (2002). The role of performance measures and incentive systems in relation to the degree of JIT implementation. Accounting, Organizations and Society, 27(8), 711-735. https://doi.org/10.1016/S0361-3682(02)00012-0

27. Gosselin, M. (1997). The effect of strategy and organizational structure on the adoption and implementation of activity-based costing. Accounting, Organizations and Society, 22(2), 105-122. https://doi.org/10.1016/S03613682(96)00031-1

28. Gunasekaran, A., Marri, H., \& Yusuf, Y. (1999). Application of activity-based costing: some case experiences. Managerial Auditing Journal, 14(6), 286-293. https://doi.org/10.1108/02686909910280217

29. Hair, J. F., Black, W. C., Babin, B. J., Anderson, R. E., \& Tatham, R. L. (1998). Multivariate data analysis (Vol. 5): Prentice Hall Upper Saddle River, NJ.

30. Hair JR, F., Babin, B., Money, H., \& Samouel, P. (2003). Essentials of Business Research Methods. 2003: John Wiley \& Sons, Inc: USA.

31. Haroun, A. E. (2015). Maintenance cost estimation: application of activity-based costing as a fair estimate method. Journal of Quality in Maintenance Engineering, 21(3), 258-270. https://doi.org/10.1108/JQME-042015-0015

32. Innes, J., \& Mitchell, F. (1995). A survey of activity-based costing in the UK's largest companies. Management accounting research, 6(2), 137-153. https://doi.org/10.1006/mare.1995.1008

33. Innes, J., Mitchell, F., \& Sinclair, D. (2000). Activity-based costing in the UK's largest companies: a comparison of 1994 and 1999 survey results. Management accounting research, 11(3), 349-362. https://doi.org/10.1006/mare.2000.0135

34. Johnson, H. T., \& Kaplan, R. S. (1987). The rise and fall of management accounting [2]. Strategic Finance, 68(7), 22. https://doi.org/10.1109/EMR.1987.4306297

35. Kennedy, T., \& Affleck-Graves, J. (2001). The impact of activity-based costing techniques on firm performance. Journal of Management Accounting Research, 13(1), 19-45. https://doi.org/10.2308/jmar.2001.13.1.19

36. Krumwiede, K. R. (1998). The implementation stages of activity-based costing and the impact of contextual and organizational factors. Journal of Management Accounting Research, 10, 239.

37. Malmi, T. (1999). Activity-based costing diffusion across organizations: an exploratory empirical analysis of Finnish firms. Accounting, Organizations and Society, 24(8), 649-672. https://doi.org/10.1016/S03613682(99)00011-2

38. McAdam, R., \& Bannister, A. (2001). Business performance measurement and change management within a TQM framework. International Journal of Operations \& Production Management, 21(1/2), 88-108. https://doi.org/10.1108/01443570110358477

39. McGowan, A. S., \& Klammer, T. P. (1997). Satisfaction with activity-based cost management implementation. Journal of Management Accounting Research, 9, 217-237.

40. Moschidis, O., Chatzipetrou, E., \& Tsiotras, G. (2018). Quality costing and quality management maturity in Greece. International Journal of Productivity and Performance Management, 67(1), 171-191. https://doi.org/10.1108/IJPPM-08-2016-0152

41. Oppenheim, A. N. (2000). Questionnaire design, interviewing and attitude measurement: Bloomsbury Publishing.

42. Pavlatos, O., \& Kostakis, H. (2015). Management accounting practices before and during economic crisis: Evidence from Greece. Advances in Accounting, 31(1), 150-164. https://doi.org/10.1016/j.adiac.2015.03.016 
43. Pierce, B., \& Brown, R. (2006). Perceived success of costing systems: Activity-based and traditional systems compared. Journal of Applied Accounting Research, 8(1), 108-161. https://doi.org/10.1108/96754260680001046

44. Ratnatunga, J. (1999). Cost and Effect: Using integrated cost systems to drive profitability and performance by Kaplan, RS and Cooper, R. Monash Mt Eliza Business Review, 19-21.

45. Schoute, M., \& Budding, T. (2017). Stakeholders' information needs, cost system design, and cost system effectiveness in Dutch local government. Financial Accountability \& Management, 33(1), 77-101. https://doi.org/10.1111/faam.12116

46. Shea, V. J., Waldrup, B. E., Xu, H., \& Williamson, S. (2018). Error Rate Impacts on Decision Efficacy: Activity-Based Costing Systems in Small Business. Quarterly Review of Business Disciplines, 5(1), 59-71.

47. Shields, M. D. (1998). Management accounting practices in Europe: a perspective from the States. Management accounting research, 9(4), 501-513. https://doi.org/10.1006/mare.1998.0081

48. Upton, D. (1998). Just-in-time and performance measurement systems. International Journal of Operations \& Production Management, 18(11), 1101-1110. https://doi.org/10.1108/01443579810231688

49. Uyar, A., \& Kuzey, C. (2016). Does management accounting mediate the relationship between cost system design and performance? Advances in accounting, 35, 170-176. https://doi.org/10.1016/j.adiac.2016.06.004

50. Wu, J., Boateng, A., \& Drury, C. M. (2007). An analysis of the adoption, perceived benefits, and expected future emphasis of western management accounting practices in Chinese SOEs and JVs. The International Journal of Accounting, 42(2), 171-185. https://doi.org/10.1016/j.intacc.2007.04.005

51. Young, S. M., \& Selto, F. H. (1991). New manufacturing practices and cost management: a review of the literature and directions for research. Journal of Accounting Literature, 10, 265-298. 